\title{
Minimally Invasive Plate Osteosynthesis with Locking Compression Plate for Distal Diametaphyseal Tibia Fracture
}

\section{Shrestha $\mathrm{D},{ }^{1}$ Acharya $\mathrm{BM}^{2}{ }^{2}$ Shrestha $\mathrm{PM}^{3}$}

\author{
${ }^{1}$ Department of Orthopaedics and Traumatology \\ Dhulikhel Hospital-Kathmandu University Hospital \\ Dhulikhel, Nepal
}

${ }^{2}$ Department of Orthopaedics

Patan Academy of Health Sciences

Patan, Nepal

${ }^{3}$ Department of Orthopaedics

Norvic International Hospital

Kathmandu, Nepal

Corresponding Author

Dr Dipak Shrestha

Department of Orthopaedics and traumatology

Dhulikhel Hospital-Kathmandu University Hospital

Dhulikhel, Nepal

E-mail: dsmsortho@gmail.com

Citation

Shrestha D, Acharya BM, Shrestha PM. Minimally invasive plate osteosynthesis with locking compression plate for distal diametaphyseal tibia fracture. Kathmandu Univ Med J 2011;34(2)62-8.

\begin{abstract}
\section{Background}

Distal diametaphyseal tibia fracture though requires operative treatment is difficult to manage. Conventional osteosynthesis is not suitable because distal tibia is subcutaneous bone with poor vascularity. Closed reduction and minimally invasive plate osteosynthesis (MIPO) with locking compression plate (LCP) has emerged as an alternative treatment option because it respects biology of distal tibia and fracture hematoma and also provides biomechanicaly stable construct.
\end{abstract}

\section{Objectives}

To find out suitability of MIPO with LCP for distal diametaphyseal tibia fracture including union time and complicatios and compare wih other available management options in literature.

\section{Methods}

Twenty patients with closed distal diametaphyseal tibia fracture with or without intra articular extension (AO classification: 12 type 43A1, 4 type 43A2, 2 type 43A3 and 2 type 43B1) treated with MIPO with LCP were prospectively followed for average duration of 18.45 months (range 5-30 months).

\section{Results}

Average duration of injury-hospital and injury-surgery interval was $12.8 \mathrm{hrs}$ (range 2-44 hrs) and 4.45 days (range 1-10 days) respectively. All fractures got united with an average duration of 18.5 weeks (range14-28weeks) except one case of delayed union which was managed with percutaneous bone marrow injection. Two patients had union with valgus angulation $<5$ degees but no nonunion was found. There were two superficial and one deep post operative wound infection. All infections healed with extended period of intravenous antibiotics besides repeated debridemet for deep infection. Implants were removed in eight patients among whom six (30\%) had malleolar skin irritation and pain due to prominent hardware.

\section{Conclusion}

The present case series shows that MIPO with LCP is an effective treatment method in terms of union time and complications rate for distal diametaphyseal tibia fracture. Malleolar skin irritation is common problem because of prominent hardware.

\section{Key Words}

Distal diametaphyseal tibia fracture; $L C P, M I P O$

\section{INTRODUCTION}

Treatment of distal diametaphyseal tibia fracture with or without articular extension is challenging because of its unique anatomical characteristics of subcutaneous location with precarious blood supply and proximity to the ankle joint. Most of these fractures are managed with an operative intervention such as closed reduction and intramedullary interlocking (IMIL) nailing or open reduction and internal fixation (ORIF) with plating or closed reduction and per cutaneous plating or external fixators. Each of these techniques has their own merits and demerits. IMIL nailing has been reported with higher rate of malunion because it is difficult to achieve two distally locking screws. ${ }^{1-3}$ Wound infection, skin breakdown and delayed union or non union requiring secondary procedures like bone grafting are some of the complications associated with conventional osteosynthesis with plates. ${ }^{4-7}$ Similarly, pin tract infection, pin loosening, malunion and nonunion leading to osteomyelitis is potential complication of external fixators and hence not preferred as definitive fixation method..$^{8-11}$ Recently, techniques of closed reduction and minimally 
invasive plate osteosynthesis (MIPO) with locking compression plate (LCP) has emerged as an alternative treatment option for distal diametaphyseal tibia fracture. When applied subcutaneously, LCP does not endanger periosteal blood supply, respect fracture heamtoma and also provides biomechanicaly stable construct. ${ }^{12,13}$ Numbers of previous clinical studies have established MIPO with LCP as a biologically friendly and technically sound method of fixation for distal diametaphyseal tibia fracture but most of these studies except by Ronga et al. and Ahmad et al. have included both open and closed fractures. ${ }^{1,14}$ Since behavior of both of these fracture are different, comparison will be not fair. We therefore prospectively studied only closed distal diametaphyseal tibia fracture with or without articular extension managed with MIPO with LCP and compared with other studies.

\section{METHODS}

Twenty patients with closed distal diametaphyseal tibia fracture with or without intra articular extension treated in three different centers in between June 2007 to July 2010 were prospectively followed. Permission from institutional review committee from all three centers was obtained. Demographic variables, mode of injury, injury-hospital and injury-surgery interval, time required for union, complications and need of secondary procedures were recorded. Fracture was classified according to AO/OTA classification system. Patients with pathological fractures, ipsilateral multiple fractures were excluded. Author DS was involved in all three centers during surgery.

\section{Surgical techniques}

Patient who presented within six hours of injury without gross swelling of leg were operated on the same day or next available day. Limbs with gross swelling were splinted and elevated till swelling subsided and wrinkles appeared over the ankle joint. Fracture blisters if present managed with puncturing with sterile needle and non-adhesive dressing and observed closely for any sign of secondary infection.

Under regional or general anesthesia, involved leg was prepared and draped. Tourniquet was routinely applied but inflated only when necessary. A vertical or curvilinear incision was made at the level of medial malleolus with the utmost care not to injure great sephaneous vein and sephaneous nerve. Sub cutaneous plane was made with hemostat without striping periosteum and disturbance to fracture haematoma. Fracture was reduced under $\mathrm{C}$ arm control. We did not use calcaneal skeletal traction or other external fixation devices. Instead, where reduction was difficult despite of repeated attempt, we made a small incision and used a Kirschner wire $(3 \mathrm{~mm})$ as a joystick to aid in fracture reduction and towel clip or reduction clamp to hold reduction. Varus -valgus angulation $<5^{\circ}$ and anteriorposterior angulation $<10^{\circ}$ and shortening of $<15 \mathrm{~mm}$ were considered acceptable criteria for reduction. Pre contoured low metaphyseal LCP was tunneled into subcutaneous plane and its position was reconfirmed with $\mathrm{C}$ arm. Before fixing the plates with screws, shagging of distal fragment was prevented by putting towel roll under the fracture site. Provisional non locking screw was applied to bring the plate on the bone. If necessary, interfragmentary compression was achieved by a screw through the plate or outside the plate. Compression osteosynthesis was achieved in simple fracture by using non locking screw on proximal to fracture site as a hybrid fixation. ${ }^{15}$ With separate stab incision, at least three locking screws were applied on the either side of fracture. Malleolar fracture if present were reduced and fixed with screws or tension band wiring before tibia fracture reduction and fixation (Figure. 1). Fibula was not routinely fixed unless it was involved at the level of syndesmosis. Skin was closed with non absorbable sutures and limb was splinted with below knee brace or posterior back slab.

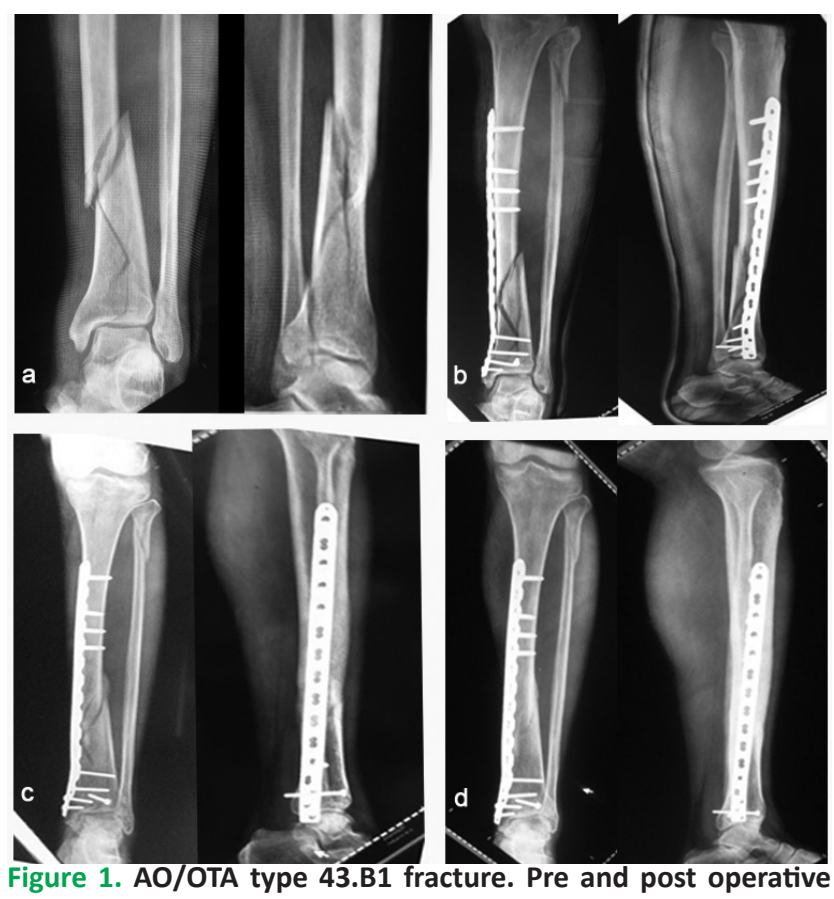

$(a, b)$ and follow up at 20 weeks (c) and 15 months (d). Note: Posterior malleolus was fixed with anterioposterior compression screw.

\section{Post operative protocol}

Wound was inspected on second post operative day for any sign of wound infection and change of dressing. Patient was discharged on second or third day of surgery if skin condition was satisfactory and wound was dry.

\section{Follow up}

On fourteen postoperative days, stitches were removed and $X$ ray of leg was obtained. Below knee brace or posterior back slab was discontinued. Intermittent ankle mobilization was initiated but weight bearing was not allowed for next four weeks. Patients were subsequently followed up in six weeks interval to asses fracture healing. Partial weight bearing was started once callus was visible in $\mathrm{X}$ ray and gradually 
Table 1. Patients and injury data.

\begin{tabular}{|c|c|c|c|c|c|c|c|c|c|c|c|}
\hline S. No. & $\begin{array}{l}\text { Age } \\
\text { (yrs) }\end{array}$ & Sex & $\begin{array}{l}\text { AO/ } \\
\text { OTA } \\
\text { Type }\end{array}$ & $\begin{array}{l}\text { Associated } \\
\text { injuries }\end{array}$ & $\begin{array}{l}\text { Mode } \\
\text { of } \\
\text { injury }\end{array}$ & $\begin{array}{l}\text { Injury- hos- } \\
\text { pital inter- } \\
\text { val (hrs) }\end{array}$ & $\begin{array}{l}\text { Injury- } \\
\text { treatment } \\
\text { interval } \\
\text { (days) }\end{array}$ & $\begin{array}{l}\text { Union time } \\
\text { (wks) }\end{array}$ & $\begin{array}{l}\text { Follow up } \\
\text { (months) }\end{array}$ & $\begin{array}{l}\text { Implant } \\
\text { removal } \\
\text { (months) }\end{array}$ & Complications \\
\hline 1 & 17 & M & 43.A1 & $\begin{array}{l}\text { Left distal radius } \\
\text { fracture }\end{array}$ & Fall & 24 & 5 & 19 & 30 & 26 & \\
\hline 2 & 38 & $\mathrm{~F}$ & 43.A1 & & Fall & 13 & 4 & 20 & 30 & 28 & $\begin{array}{l}\text { Valgus angula- } \\
\text { tion }<5^{\circ}\end{array}$ \\
\hline 3 & 35 & $M$ & 43.A1 & & RTA & 28 & 3 & 17 & 30 & 24 & \\
\hline 4 & 29 & M & 43.A1 & & RTA & 8 & 1 & 17 & 28 & 24 & Deep infection \\
\hline 5 & 35 & $\mathrm{~F}$ & 43.A3 & & RTA & 5 & 6 & 18 & 25 & 20 & \\
\hline 6 & 20 & $\mathrm{~F}$ & 43.A3 & $\begin{array}{l}\text { Contralateral } \\
\text { diaphyseal tibia } \\
\text { fracture, head } \\
\text { injury and soft } \\
\text { tissue contusion }\end{array}$ & RTA & 4 & 1 & 17 & 24 & 20 & \\
\hline 7 & 21 & $\mathrm{~F}$ & 43.A1 & Fracture blisters & RTA & 44 & 10 & 28 & 24 & & $\begin{array}{l}\text { Superficial } \\
\text { infection, de- } \\
\text { layed union }\end{array}$ \\
\hline 8 & 32 & $\mathrm{~F}$ & 43.A1 & & RTA & 2 & 2 & 16 & 22 & 16 & \\
\hline 9 & 65 & $\mathrm{~F}$ & 43.A1 & & Fall & 7 & 3 & 20 & 22 & 20 & \\
\hline 10 & 42 & M & 43.A1 & & Fall & 2 & 5 & 20 & 15 & & \\
\hline 11 & 40 & $\mathrm{~F}$ & 43.A2 & & RTA & 5 & 6 & 18 & 15 & & Ankle stiffness \\
\hline 12 & 44 & M & 43.B1 & $\begin{array}{l}\text { Left distal radius } \\
\text { fracture }\end{array}$ & RTA & 4 & 5 & 16 & 15 & & \\
\hline 13 & 38 & M & 43.A1 & & Assault & 12 & 5 & 16 & 15 & & \\
\hline 14 & 27 & M & 43.A2 & & Sports & 9 & 6 & 20 & 14 & & $\begin{array}{l}\text { Valgus angula- } \\
\text { tion }<5^{\circ}\end{array}$ \\
\hline 15 & 28 & $\mathrm{~F}$ & 43.A1 & & Fall & 7 & 2 & 14 & 13 & & $\begin{array}{l}\text { Superficial } \\
\text { infection }\end{array}$ \\
\hline 16 & 25 & M & 43.A1 & & RTA & 6 & 2 & 20 & 12 & & \\
\hline 17 & 52 & $\mathrm{~F}$ & 43.A2 & & Fall & 22 & 4 & 18 & 12 & & \\
\hline 18 & 30 & M & 43.A1 & & Fall & 18 & 5 & 20 & 10 & & \\
\hline 19 & 29 & M & 43.B1 & & RTA & 20 & 8 & 18 & 8 & & \\
\hline 20 & 34 & M & 43.A2 & Fracture blisters & Fall & 16 & 6 & 18 & 5 & & \\
\hline
\end{tabular}

increased according to clinical and radiological signs of fracture healing. Fracture was considered united when visible bridging callus was seen in at least three cortices in anterior-posterior and lateral $x$ rays of leg and absence of pain on weight bearing clinically. If fracture union was not progressing satisfactorily, secondary procedures like bone marrow injection or cortico-cancellous bone grafting were considered. Malunion was defined as varus -valgus angulation $\geq 5^{\circ}$ and anterior-posterior angulation $\geq 10^{\circ}$ and shortening of $\geq 15 \mathrm{~mm}$. During subsequent follow up once fracture united, if patents wished to remove the hardware or had hardware related complaints like malleolar pain, difficulty of wearing shoes or prominent implants, plate removal was indicated.

Statistical analysis was performed by using SPSS (Chicago, Illinois, USA) version 15 software for Window. Mann Whitney $U$ test was used for comparison. A p value $<0.05$ was regarded as significant.

\section{RESULTS}

There were 12 male (mean age 30.9 yrs, range17-42 yrs) and eight female patients (mean age 38.75 yrs, range 20$65 y r s)$. According to $A O$ classification, 12 (60\%) of fracture were 43A1, 4 (20\%) 43A2, 2 (10\%) $43 A 3$ and 2 (10\%) 43B1. Half of the patients sustained injury in road traffic accident. Other modes of injury were fall injury in $8(40 \%)$ patients and physical assault and sports related injury in 1 (5\%) each. One patient had contralateral diaphyseal tibia fracture which was managed with closed reduction and IMIL nailing in same setting. Average duration of injury-hospital and injury-surgery interval was $12.8 \mathrm{hrs}$ (range 2-44 hrs) and 4.45 days (range 1-10 days) respectively. In two patients case no 7 and 19, repeated attempt of closed reduction failed and hence small opening was made at fracture site to apply a towel clip and Kirschner wire as joystick to assist reduction. Patients were followed up for average duration of 18.45 months (range 5-30 months). No single case of injury to great sephaneous vein and sephaneous nerve was detected. Average duration for fracture union was 
18.5 weeks (range14-28weeks). Demographic profiles and outcome of each case are tabulated in table 1.

Immediate post operative complication of wound infection was found in three patients; two superficial (case no 7, 16) and one (case no 4) deep wound infection. Case no. 7 was brought to hospital after 44 hours of fall injury from remote part of country with swollen leg and fracture blisters. He was operated after 10 days of injury once blisters and swelling settled down. During subsequent follow up to 18 weeks, fracture union was not progressing satisfactorily and hence, was subjected for percutaneous bone marrow injection at fracture site. Finally fracture got united at 28 weeks. In case no 4, wound was dry and non infected at time of discharge on fifth post operative day but came back with wound breakdown and exposed plate. He had a history of application of homemade herbal paste over the wound and fracture site. Both superficial wound infections healed with extended period of intravenous antibiotics but patient with wound breakdown needed repeated debridemet as well. Subsequent follow up was unremarkable in all these three cases.

Two patients had union with valgus angulation of less than $5^{\circ}$. No malunion was detected. One patient had ankle stiffness requiring extensive physiotherapy to regain range of movement.

Implants were removed in eight patients. Six of them had malleolar skin irritation due to prominent hardware and in rest of two patients; implants were removed on request. No problems were encountered during removal of implants.

\section{DISCUSSION}

Distal diametaphyseal tibia fracture with or without intra articular extension is one of the difficult fractures to manage. None of the treatment options available perfectly fulfill requirements of fracture characteristics of distal diametaphyseal tibia. Distal tibia has got circular cross sectional area with thinner cortex as compare to triangular diaphysis with thicker cortex. So, intramedullary nail which is designed for tight interference fit at diaphysis cannot provide same stability at distal fracture. ${ }^{3,16}$ Other potential complications of IMIL nailing are malunion (0-29\%) and implant failure (5-39\%)..$^{1-3}$ ORIF with conventional plate which needs striping of periosteum is also not an ideal treatment option because tibia is subcutaneous bone and periosteum provides $2 / 3$ rd of blood supply. Non union, delayed union and infection are reported with the range of $8.3-35 \%$ and $8.3-25 \%$ respectively with ORIF with plating. ${ }^{4-7,17}$ Similarly external fixators as a definitive method of treatment for distal diametaphyseal tibia fracture are also reported with higher rate of infection, implant failure and malunion or non union and hence recommended only for temporary method of stabilization in open fracture with severe soft tissue injury. ${ }^{1,18}$

With the development of technique of MIPO with LCP which preserve extraosseous blood supply, respect osteogenic fracture haematoma, biologically friendly and stable fixation method is available for distal diametaphyseal tibia fracture. Indirect reduction method and sub-cutaneous tunneling of the plate and application of locking screws with small skin incisions in MIPO technique prevents iatrogenic injury to vascular supply of the bone. ${ }^{19}$ Unlike conventional plates, LCP is a friction independent self stable construct which provides both angular and axial stability and minimizes risk of secondary loss of reduction through a threaded interface between the screw heads and the plate body. ${ }^{12}$

MIPO with LCP for distal diametaphyseal tibia fracture has been found to be an effective treatment option.1,14,15,20-25 Table 2 shows comparison of current study with some of the previous studies. But unlike the present study, most of the previous studies have included both open and closed fractures and are retrospective study. Comparative studies with IMIL or conventional open techniques have found conflicting results with MIPO with LCP for distal diametaphyseal tibia fracture. Vallier et al. reported significantly more angular malalignment in distal diametaphyseal tibia fracture, treated with IMIL in comparison to those treated with plating ( 22 patients vs 2 patients, $p=0.003$ ) where as Guo et al. in a comparative study of extra articular distal diametaphyseal tibia fracture reported that patients treated with IMIL nailing had better function, alignment and American Orthopedic Foot Ankle score, though none of them were statistically significant where as operative time ( 81.33 vs. 97.9 minutes, $p<0.001)$ and radiation exposure ( 2.12 vs. 3 minutes, $p<0.001$ ) was significantly more in LCP group and higher mean pain score was found in IMIL group. ${ }^{6,8}$ Cheng et al. in a small sampled paired comparison (15 in each group) of MIPO and open technique with LCP found former is not statistically better in terms of union time (16.8 vs., 19.2 wks, $p=0.737$ ), recovery time to return to work (21.1 vs. 27.7 weeks, $\mathrm{p}=0.35$ ) and functional results. ${ }^{26}$ Kao et al. found no statistically significant advantages of LCP over conventional plate group. ${ }^{27}$

In spite of use of MIPO with LCP as internal external fixators, anatomical reduction of the fracture by using indirect reduction maneuvers before applying the plate is very important surgical step. Malreduction and suboptimal pre contouring of the plate can result delayed union, non union, prominent hardware, malleolar skin irritation and pain. . $3,24,26$ In the present study, pain and malleolar skin irritation in six (30\%) patients was common indication of implant removal. Other indications were difficulty of wearing shoes and cosmetic concern because of prominent hardware in skinny and thin patient (Fig. 2). Low profile metaphyseal LCP has been designed to reduce hardware prominence related complications but plates specifically designed according to measurement of adult distal tibia of western population may not perfectly match to other communities and often need change in pre contouring to avoid mismatch which in turn, can change the direction 
Table 2. Comparison of current study with previous clinical series.

\begin{tabular}{|c|c|c|c|c|c|}
\hline Study & No of fractures & Study Method & Fixation & Outcomes & Complications \\
\hline Ronga $\mathrm{M}$ et al. [1] & 19 & Retrospective & MIPO & $\begin{array}{l}\text { Union: } 18 \text { (22.3 wks, } \\
\text { range } 12-24)\end{array}$ & $\begin{array}{l}\text { Nonunion: } 1 \\
\text { No malunion ( } \geq 7^{\circ} \text { deformity or } \geq 1 \mathrm{~cm} \text { LLD) } \\
\text { Deep infection:3 }\end{array}$ \\
\hline Ahmad MA et al. [14\} & 18 & Retrospective & MIPO & Union: 15 (21.2 wks) & $\begin{array}{l}\text { Delayed union: } 3 \\
\text { Superficial wound infarction: } 1 \\
\text { Chronic wound infection: } 1 \\
\text { Implant failure: } 1\end{array}$ \\
\hline $\begin{array}{l}\text { Hasenbohehler E et } \\
\text { al. [9\} }\end{array}$ & 32 (open fracture: 8) & Retrospective & MIPO & $\begin{array}{l}\text { Union: } 29 \text { ( } 27.7 \text { wks, } \\
\text { range } 24-60 \text { ) }\end{array}$ & $\begin{array}{l}\text { Nonunion: } 2 \\
\text { No malunion }\left(\geq 5^{\circ} \text { deformity or } \geq 1 \mathrm{~cm} \text { LLD) }\right. \\
\text { Plate bending }\left(18^{\circ}\right): 1 \\
\text { Pseudoarthrosis: } 2\end{array}$ \\
\hline Hazarika S et al. [21] & 20 (open fracture: 8) & Retrospective & MIPO & $\begin{array}{l}\text { Union: } 18 \text { ( } 28.5 \text { wks, } \\
\text { range, 9-68) }\end{array}$ & $\begin{array}{l}\text { Nonunion: } 2 \\
\text { Delayed wound break down: } 2 \\
\text { Wound infection: } 1 \\
\text { Implant failure: } 1 \\
\text { Secondary procedure: } 2\end{array}$ \\
\hline Bahari S et al. [25] & 42 (open fracture: 8 ) & Prospective & MIPO & Union: 42 (22.4 wks) & $\begin{array}{l}\text { No malunion } \\
\text { Superficial wound infection: } 2 \\
\text { Deep infection: } 1 \\
\text { Implant failure: } 1\end{array}$ \\
\hline Collinge $C$ et al.[15] & 38 (open fracture: 8) & Prospective & MIPO & $\begin{array}{l}\text { Union: } 38 \text { ( } 21 \text { wks, } \\
\text { range } 9-48 \text { ) }\end{array}$ & $\begin{array}{l}\text { Malunion ( } \geq 5^{\circ} \text { deformity) : } 1 \\
\text { Secondary procedure: } 3\end{array}$ \\
\hline Mushtaq A et al. [20] & 21 (open fracture: 4) & Prospective & MIPO & $\begin{array}{l}\text { Union: } 21 \text { ( } 5.5 \\
\text { months, range 3-13) }\end{array}$ & $\begin{array}{l}\text { Delayed union: } 1 \\
\text { Non union :1 } \\
\text { Wound infection: } 2 \\
\text { Secondary procedure: } 2\end{array}$ \\
\hline Lau TW et al. [30] & 48 (open fracture: 9) & Retrospective & MIPO & $\begin{array}{l}\text { Union: } 47 \text { ( } 18.7 \text { wks, } \\
\text { range } 12-44 \text { wks) }\end{array}$ & $\begin{array}{l}\text { Delayed union: } 5 \\
\text { Wound infection: } 8 \\
\text { Secondary procedure: } 1\end{array}$ \\
\hline Gupta RK et al.[23] & 80 (open fracture:19) & Retrospective & $\begin{array}{l}\text { MIPO : } 71 \\
\text { Open: } 9\end{array}$ & $\begin{array}{l}\text { Union: } 77 \text { (19 wks, } \\
\text { range 16-32) }\end{array}$ & $\begin{array}{l}\text { Delayed union :7 } \\
\text { Non union: } 3 \\
\text { Malunion ( } \geq 5^{\circ} \text { deformity or } \geq 1 \mathrm{~cm} \text { LLD): } 2 \\
\text { Wound infection: } 1 \\
\text { Wound breakdown: } 2 \\
\text { Secondary procedure: } 2\end{array}$ \\
\hline Current study & 20 & Prospective & MIPO & $\begin{array}{l}\text { Union: } 20 \text { (18.5 wks, } \\
\text { range } 14-28)\end{array}$ & $\begin{array}{l}\text { Delayed union : } 1 \\
\text { No malunion ( } \geq 5^{\circ} \text { deformity or } \geq 1 \mathrm{~cm} \text { LLD) } \\
\text { Superficial wound infection: } 2 \\
\text { Deep infection: } 1 \\
\text { Secondary procedure: } 1\end{array}$ \\
\hline
\end{tabular}

of screws in monoaxial type of locking compression plates. ${ }^{23}$ Polyaxial locking plates can be an alternative when supramalleolar anatomy mismatch with pre contoured plate because it can provide choice of screw trajectories according to fracture pattern. ${ }^{24}$ But there is very little clinical and biomechanical study of polyaxial locking plates for distal tibia.

Indirect reduction of fracture under $\mathrm{C}$ arm control can be difficult at time. Various reduction maneuvers such as calcaneal pin traction, external fixators or mechanical distractors have been described to achieve reduction., ${ }^{1,22}$ We used Kirschner wires $(3 \mathrm{~mm})$ as a joystick or a towel clip after making small opening at fracture site whenever reduction could not be achieved by mechanical traction. Concomitant fibula fracture also play the role in success of reduction especially when fracture is at same level of tibia. Some authors recommend fibula fixations before tibia fixation to achieve better tibial alignment and to prevent valgus malalignment but clear indications for fibula

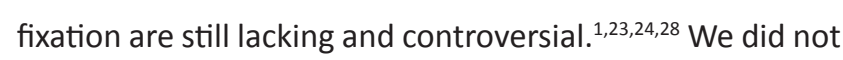
routinely fix fibula unless it has involved syndesmosis.

MIPO technique can restore alignment in high velocity distal diametaphyseal tibia fracture and patients can
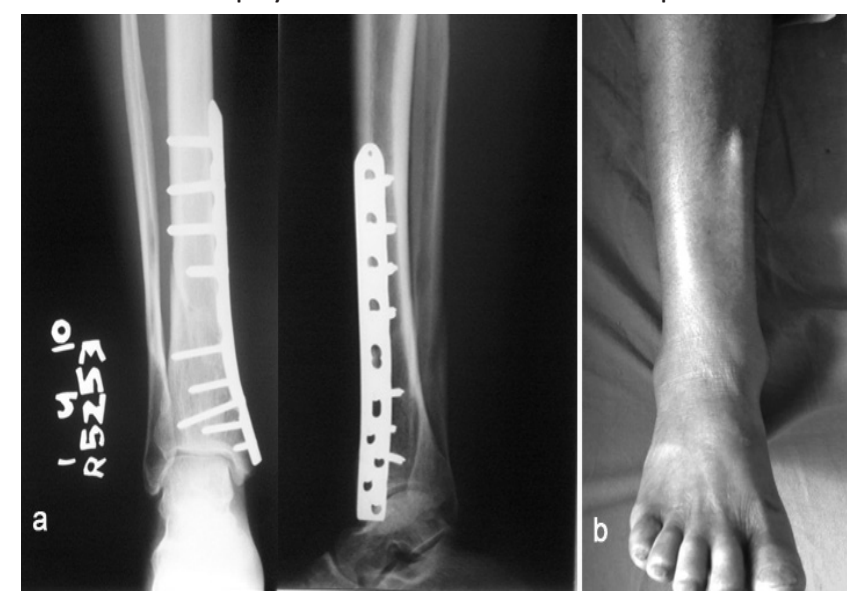

Figure 2. Fracture (AO/OTA type 43.A1) united (a) but clearly visible prominent hardware over skinny and thin patient (b). 
expect predictable return of function. However, Collinge et al. reported increased secondary procedure rate like bone grafting for delayed union. ${ }^{29}$ Rate of secondary procedures like iliac crest bone grafting or per cutaneous bone marrow injection for delayed union or non union or change of hardware has been reported $3.8 \%$ to as high as up to $35 \% .{ }^{23,29}$ In the current study, one patient required subcutaneous bone marrow injections as satisfactory callus was not visualized up to 16 weeks follow up. He subsequently had progressive callus formation.

Because of sub cutaneous location, distal diametaphyseal tibia are prone to have gross swelling, skin injury and fracture blisters if the leg is left unsplinted for long time and injury-hospital arrival interval is prolonged. In the current series, 13 patients who had injury- surgery interval of $>3$ days had average injury- hospital arrival interval $14.92 \mathrm{hrs}$ as compare to $8.86 \mathrm{hrs}$ in seven patients who were operated within three days of injury. Our protocol for timing of surgery was to fix the fracture as early as possible unless associated with gross swelling or hindered by fracture blisters. But union time in our study was not affected whether patients were operated before or after three days of injury $(17.29 \pm 2.13$ wks vs. $19.15 \pm 2.99$ $w k s, p=0.15)$. The average time for fracture union in the present study is comparable to other studies (Table 2). Hasenboehler et al. found MIPO with LCP though reliable for distal diametaphyseal tibia fracture can prolong union time in simple fracture pattern (43.A1-43.A3) when it was used only as a bridging plate. ${ }^{9}$ Hence, percutaneous interfragmentary screw, independent to plate and LCP in a neutralization mode or application of LCP in a compression mode by utilizing non locking screw on one side of the fracture is recommended to avoid delay in fracture union.

Though skin and soft tissue injury at the time of conventional osteosynthesis has been found to be significantly associated with higher rate of wound infection as compare to IMIL nailing, effect of same on MIPO with LCP has not been studied yet. ${ }^{10}$ Lau et al. did not find fracture union time in MIPO to be affected by presence of late infections occurring after one month of complete wound healing. ${ }^{30}$ Reported rate of wound infection varies between $2.6 \%$ to $14.6 \%$ depending upon whether open fracture are included in the study or not. The present study which included only closed fracture found three (15\%) early wound infection. Two patients who had superficial wound infection improved with antibiotics but patient with wound breakdown and exposed implant had protracted post operative rehabilitation period requiring repeated wound debridemet and long hospital stay.

Other potential complications like injury to sephaneous nerve and great sephaneous vein has been reported in cadaver studies and can be avoided by careful attention towards selection of skin incision site, dissection of vein, dissection of stab incision up to the plate and atraumatic placement of drill sleeve. ${ }^{26,31}$ No case of sephaneous nerve and great sephaneous vein was found in the current study.
Removal of LCP can be difficult because usual conical extraction devices may not be useful in locking screws when stripping of hexagonal recess or thread occurs. Cutting and bending of plate around the stripped screw has been suggested to remove the plates and screws but we did not encounter problems during removal of implants in all our eight cases. ${ }^{23,32}$

\section{CONCLUSION}

Distal diametaphyseal tibia fracture with or without intra articular extension is one of the difficult fractures to manage with all currently available treatment options. Fracture pattern, concomitant articular extension, condition of soft tissue are important factors to be considered before selection of fixation method. The present case series though small in number shows that MIPO with LCP is an effective treatment method in terms of union time and complications rate which is comparable to other studies. Implant prominence and its related complications because of mismatching of the implant contouring and supra malleolar anatomy especially in thin built patients or malreduction of fracture still remains a challenge. Prospective randomized controlled trial specially comparing newly available intramedullary nails which has various distal locking options is necessary to establish superiority of the technique.

\section{REFERENCES}

1. Ronga M, Longo UG, Maffulli N. Minimally invasive locked plating of distal tibia fractures is safe and effective. Clin Orthop Relat Res 2010, 468:975-82.

2. Mosheiff R, Safran $O$, Segal D, Liebergall M. The unreamed tibial nail in the treatment of distal metaphyseal fractures. Injury 1999,30:83-90.

3. Kneifel T, Buckley R. A comparison of one versus two distal locking screws in tibial fractures treated with unreamed tibial nails: a prospective randomized clinical trial. Injury 1996, 27:271-273.

4. Redfern DJ, Syed SU, Davies SJM. Fractures of the distal tibia: minimally invasive plate osteosynthesis. Injury 2004, 35:615- 620.

5. Apivatthakakul T, Phornphutkul C, Patumasutra S. Idea and innovation: Simple minimally invasive plate osteosynthesis (MIPO) instruments. Injury Extra 2009,40:39-44.

6. Vallier HA, Le TT, Bedi A. Radiographic and clinical comparisons of distal tibia shaffractures (4 to $11 \mathrm{~cm}$ proximal to the plafond): plating versus intramedullary nailing. J Orthop Trauma 2008, 22:307-11.

7. Yang SW, Tzeng HM, Chou YJ, Teng HP, Liu HH, Wong CY. Treatment of distal tibial metaphyseal fractures: Plating versus shortened intramedullary nailing. Injury 2006, 37:531-535.

8. Guo JJ, Tang N, Yang HL, Tang TS. A prospective, randomised trial comparing closed intramedullary nailing with percutaneous plating in the treatment of distal metaphyseal fractures of the tibia. J Bone Joint Surg Br 2010, 92-B:984-8.

9. Hasenboehler E, Rikli D, Babst R. Locking compression plate with minimally invasive plate osteosynthesis in diaphyseal and distal tibial fracture: a retrospective study of 32 patients. Injury 2007, 38:365-70. 
10. Gun-II Im, Suk-Kee Ta. Distal metaphyseal fractures of tibia: A prospective randomized trial of closed reduction and intramedullary nail versus open reduction and plate and screws fixation. J Trauma 2005,59:1219-1223.

11. Watson JT, Moed BR, Karges DE, Cramer KE. Pilon fractures. Treatment protocol based on severity of soft tissue injury. Clin Orthop Relat Res 2000, 375:78-90.

12. Wagner M, Frigg FR. Locked plating: Biomechanics and biology and locked plating: Clinical indications. Techniques in Orthopaedics 2007, 22(4) :209-218.

13. Frigg R. Development of the locking compression plate. Injury Suppl 2003, 2:B6-B10.

14. Ahmad MA, Sivaraman A, Zia A, Rai A, Patel AD. Percutaneous locking plates for fractures of the distal tibia: Our experience and a review of the literature. J Trauma 2010, doi: 10.1097/TA.0b013e3181f140b3

15. Collinge C, Protzman R. Outcomes of minimally invasive plate osteosynthesis for metaphyseal distal tibia fractures. J Orthop Trauma 2010, 24:24-29.

16. Trafton PG .Tibial Shaft Fracturs. In: Skeletal trauma. 4th edn. Edited by Browner DB, Jupiter JB, Levine AN, Trafton PG, Krettek C. Philadelphia: Suanders Elsevier; 2009:2319-2452.

17. Megas P, Zouboulis $P$, Papadopoulos AX, Karageorgos A, Lambiris E. Distal tibial fractures and non-unions treated with shortened intramedullary nail. Inter Orthop 2003, 27:348-35.

18. Joveniaux $P$, Ohl $X$, Harisboure A, Berrichi A, Labatut $L$, Simon $P$, Mainard D, Vix N, Dehoux E. Distal tibia fractures: management and complications of 101 cases. Inter Orthop 2010, 34:583-588.

19. Borrelli J, Prickett W, Song E, Becker D, Ricci W. Extra osseous blood supply of the distal tibia and the effects of different plating techniques: Human cadaveric study. J Orthop Trauma 2002, 16:691- 695.

20. Mushtaq A, Shahid R, Asif M, Maqsood M. Distal tibial fracture fixation with locking compression plate (LCP) using the minimally invasive percutaneous osteosynthesis (MIPO) technique. Eur J Trauma Emerg Surg 2009, 35:159-64.

21. Hazarika S, Chakravarthy J, Cooper J. Minimally invasive locking plate osteosynthesis for fractures of the distal tibia-results in 20 patients. Injury 2006, 37:877-887.
22. Shanmugam C, Rahmatalla A, Maffulli N. Percutaneous fixation of distal tibial fractures using locking plates. Techniques in Orthopaedic 2007, 22(3):162-166.

23. Gupta RK, Rohilla RK, Sangwan K, Singh V, Walia S. Locking plate fixation in distal metaphyseal tibial fractures: series of 79 patients. Inter Orthop 2010, 34:1285-1290.

24. Gao H, Zhang CQ, Luo CF, Zhou ZB, Zeng BF. Fractures of the distal tibia treated with polyaxial locking plating. Clin Orthop Relat Res 2009, 467:831- 837.

25. Bahari S, Lenehan B, Khan H, Mcelwain JP. Minimally invasive percutaneous plate fixation of distal tibia fractures. Acta Orthop Belg 2007, 73:635-640.

26. Cheng W, Li Y, Manyi W. Comparison study of two surgical options for distal tibia fracture-minimally invasive plate osteosynthesis vs. open reduction and internal fixation. Inter Orthop 2010, doi: 10.1007/ s00264-010-1052-2

27. Kao FC, Tu YK, Hsu KY, Wu CH, Yen Cy, Chou MC. Treatment of distal tibial fractures by minimally invasive percutaneous plate osteosynthesis of three different plates: Results and cost-effectiveness analysis. Formosan Journal of Musculoskeletal Disorders 2010, 1:35-40.

28. Bedi A, Le TT, Karunakar MA. Surgical treatment of nonarticular distal tibia fractures. J Am Acad Orthop Surg 2006, 14:406-416.

29. Collinge C, Kuper M, Larson K, Protzman R. Minimally invasive plating of high energy metaphyseal distal tibia fractures. J Orthop Trauma 2007, 21:355-61.

30. Lau TW, Leung F, Chan CF, Chow SP. Wound complication of minimally invasive plate osteosynthesis in distal tibia fractures. Inter Orthop 2008, 32:697-703.

31. Ozsoy MH, Tuccar E, Demiryurek D et al. Minimally invasive plating of the distal tibia: do we really sacrifice saphenous vein and nerve? A cadaver study. J Orthop Trauma 2009, 23(2):132-138.

32. Bae JH, Oh JK, Oh CW, Hur CR. Technical difficulties of removal of locking screw after locking compression plating. Arch Orthop Trauma Surg 2009, 129:91-5. 